\title{
Eco Friendly Management of Alternaria sp. causing Leaf Spot of Bitter Gourd (Momordica charantia L.)
}

\author{
Mounika Chavan*, Shashi Tiwari, Mandala Mahesh and Katukamsairam \\ Department of Plant Pathology, Sam Higginbottom University of Agriculture, Technology and \\ Sciences, Prayagraj, U.P. India \\ *Corresponding author
}

\section{Keywords}

Alternaria Leaf spot, bio-agents, neem oil, management, Trichoderma viride

Article Info

Accepted:

20 May 2021

Available Online:

10 June 2021
Bitter gourd (Momordica charantia L.) is one of the most important cucurbitaceous vegetable crops being grown both during warm and rainy season in northern parts of India. It has wide genetic diversity and is grown throughout the tropics and subtropics of the world. But the crop is attacked by a number of diseases such as Anthracnose leaf spot, Alternaria leaf blight, Cercospora leaf spot, powdery mildew, downy mildew and anthracnose, amongst which leaf spot caused by Alternaria spp. is found to cause serious losses throughout Uttar pradesh and other states. A field trail in Rabi season in the month of febraury the effect of seed treatment with bio-agents and Neem oil were minimize the leaf spot disease severity of bitter gourd. On the basis of single trail it was observed that seed treatment with Neem oil @2.5\% + T. viride@2.5\% was most in-effectual against leaf spot disease.

\section{Introduction}

Bitter gourd (Momordica charantia.L.) is considered to be originated either in Tropical Africa or Indo-Burma region. It is known as Karela in Hindi and Karavellika in Sanskrit. Bitter gourd is one of the most popular vegetable of cucrbitaceae family in the tropical and subtropical countries (Palada and Chang, 2003 and Win et al., 2014). It is widely grown throughout South-east Asian countries including India, China and Nepal
(Abascal and Yarnell, 2005 and Raj et al., 2010). It is also grown in Africa, Caribbean and South America as a food and Medicine (Nadkarni, 1993; Warrier et al., 1995; Kumar et al., 2010). Bitter gourd is a popular and demanded vegetable among cucurbits grown in India. India is the second largest producer of vegetables in the world next to china with a production of 181 million tons from an area of 9.575 million hectares with productivity of 17.7 million tons per hectare. In India it is cultivated in an area of 87 thousand million ha 
with a production of 917 thousand MT. India shares about $13.4 \%$ of the world's vegetable production from about $2.0 \%$ of total cropped area (NHB, 2017). In India, the bitter gourd growing states are Andhra Pradesh, Tamil Nadu, Kerala, Karnataka, Maharashtra, Gujarat, Rajasthan, Punjab, West Bengal, Orissa, Assam, Uttar Pradesh and Bihar (Anonymous, 2018).

Bitter gourd is known as balsam pear, bitter melon, bitter cucumber, African cucumber, karela and ampalaya (Behera et al., 2010). The immature fruits are boiled, curried stuffed or sliced and fried, before consumption. The fruits are also pickled, canned and dehydrated. Bitter gourd fruits are good source of carbohydrate, protein, mineral, vitamin and have highest nutritive value among cucurbits (Desai and Musmade, 1998). 100gm of bitter gourd fruit contains $5.6 \mathrm{~g}$ protein, $290 \mathrm{mg}$ of calcium, 5mg iron, $5.1 \mathrm{mg}$ vitamin A, 170mg vitamin $\mathrm{C}$ and $55 \mathrm{mg}$ of inorganic phosphorus, small amount of vitamin B complex.

Bitter gourd is commonly attacked by number of diseases such as downy mildew, powdery mildew, gummosis, Phytophtora blight, collar rot, Fusarium wilt, White rot, damping off of seedlings and fungal root rots, root knot nematode, bacterial wilt, bacterial leaf spot, mosaic, watermelon bud necrosis, leaf curl and leaf distortion virus. These diseases are of national importance and cause important economic losses in cucurbits (Mathew and Alice, 2002; Palada and Change, 2003; Rai et al., 2005 and Khan et al., 2014).

Spraying neemarin and neem oil helps in reducing the disease development by washing the leaf surface wet with dew droplets. The presence of the few anti nutrients like saponins, tannins, glycosides, alkaloids, terpenes and flavenoids in the extract of aqueous and oils of Azardireachta indica to be responsible in inhibiting mycelia growth of the pathogen. In the castor oil the antifungal activity was due to ricinoleic acids their corresponding salts and oleic acid have been displayed antimicrobial activity (Nieman 1995; Sprong et al., 2001; Skrivanova et al., 2005). It is been assumed that the fatty acids penetrate the lipid membrane and dissociate in the more alkaline interior causing the metabolic uncoupling. In addition, the high inhibition caused by the ricinoleic acid could due to its cytolytic activity by being a solvent of chitin, constituent of the cell membrane of fungi, while the oleic acid has potential antifungal properties attribution to long chain unsaturartion (Agoramoorthy et al., 2007).

Thus, these finding could be significant for an understanding of the basis of the $R$. communi soil effect on $C$. gloeosporioides.

In clove there is high concentration of the eugenol (83.6\%) an antiseptic phenolic compound that can attribute to control the development of microorganism (costa et al., 2011). The major compound is the thyme essential oil are thymol, p-cymene and alphaterpinene who components have antimicrobial activities (Jakiemiu et al., 2010).

\section{Materials and Methods}

\section{Identification of Alternaria sp. from infected plant}

The typical symptoms of leaf spot observed in the field were small, scattered, circular to oval, yellowish to brown colour spots with concentric rings. Later, several such spots progressed, became irregular and bigger in size. The well developed spots coalesced to form big patches on leaves exhibiting blighted look. Generally, older leaves are infected more severely than younger ones. Keeping in view, the present study was undertaken to aware the management of leaf spot disease in bitter gourd. 
Conidiophores dark, mostly simple; determinate or sympodial, rather short or elongate; conidia (porospores) dark, typically with both cross and longitudinal septa; variously shaped, obclavate to elliptical or ovoid, frequently borne acropetally in apical simple or branched appendage; parasitic or saprophytic on plant material (Barnett and Hunter 1998).

\section{Preparation and application of seed treatment:}

\section{Neem oil}

Neem oil was measured $5 \mathrm{ml}$ with the help of measuring cylinder, was then mixed thoroughly with $100 \mathrm{gm}$ of seeds in a conical flask. The seeds were treated until they were saturated that is around 5-10 minutes (Pratibha et al., 2005). It adhered to the seeds due to sticky nature and sown in the furrow 2 seeds at each point keeping the spacing at $30 \mathrm{~cm}$ in between.

\section{Castor oil}

Castor oil was measured $5 \mathrm{ml}$ with the help of measuring cylinder, was then mixed thoroughly with $100 \mathrm{gm}$ of seeds. The seeds were treated until they were saturated that is around 5-10 minutes (Rahmatzai et al., 2017).

\section{Clove oil}

Clove oil was measured $5 \mathrm{ml}$ with the help of measuring cylinder, was then mixed thoroughly with $100 \mathrm{gm}$ of seeds. The seeds were treated until they were saturated that is around 5-10 minutes (Divyajagan, et al., 2018).

\section{Bio-agent, Trichoderma viride}

Trichoderma sp. was isolated from the soil of the experimental field with the help of serial dilution technique. Culture proliferation was done with the help of single spore technique. Thereafter, with the help of scalpel 5 grams of mycelium was taken and mixed with talc powder. The prepared powder formulation was then used for seed treatment (Ravishankar et al., 2018).

\section{Neem oil $+T$. viride}

Neem oil was measured $2.5 \mathrm{ml}$ with the help of measuring cylinder and $2.5 \mathrm{gm}$ of bio-agent power was measured, then mixed thoroughly with $100 \mathrm{gm}$ of seeds (Gayathri et al., 2018).

\section{Castor oil + T. viride}

Clove oil was measured $2.5 \mathrm{ml}$ with the help of measuring cylinder and $2.5 \mathrm{gm}$ of bio-agent power was measured, then mixed thoroughly with $100 \mathrm{gm}$ of seeds.

\section{Clove oil $+\mathbf{T}$. viride}

Castor oil was measured $2.5 \mathrm{ml}$ with the help of measuring cylinder and $2.5 \mathrm{gm}$ of bio-agent power was measured, then mixed thoroughly with $100 \mathrm{gm}$ of seeds (Kader et al., 2012).

\section{Disease severity}

Per cent disease intensity was recorded at 30, $60 \& 90$ days after incidence of Alternaria. Percentage of Disease severity was calculated in accordance with following formula. The severity of disease was visually assessed in all the plots at weekly interval from first appearance of disease for each treatment. For each plot, the number of infected bitter gourd plants were counted and expressed as a percentage of the total number of bitter gourd plants in that plot. The mean percentage disease severity for each treatment was obtained from the three replications. The data was further statistically analyzed. Disease severity is the percentage of relevant host 
tissues or organ covered by symptoms or lesion or damage by the the disease. Severity results from the number and size of the lesions. Disease severity shows about the extent of damage caused by the disease.

Disease severity (\%) was calculated by using the following formula:

$$
\begin{aligned}
& \text { Disease severity }(\%) \\
& \text { Sum of all disease rating } \\
& \text { = --y no. of x maximum } \\
& \begin{array}{l}
\text { Total } \\
\text { rating disease grade }
\end{array}
\end{aligned}
$$

\section{Results and Discussion}

\section{Effect of treatments on plant height (cm) of bitter gourd at different DAS interval}

Perusal of data (Table 1 and Figure 1) revealed maximum plant height $(\mathrm{cm})$ in Neem oil+ T. viride treatment at 30,60 and 90 days after sowing (121.29, 168.11 and 280.64, respectively),followed by, Castor oil $+T$. viride treatment $(116.08,153.08$ and 275.12, respectively),Clove + T.viride treatment (112.88,150.21 and 260.60, respectively), Trichoderma viride treatment $(111.87,148.05$ and 250.95, respectively), Neem oil treatment(108.85,140.22and 235.11, respectively), Clove oil treatment (93.97, 135.15 and 220.09, respectively), Castor oil treatment $(88.36,130.68$ and 216.30, respectively) and untreated check (77.85, 128.76 and 205.32, respectively). Among the treatments (T2, T7 and T3), (T5, T4,), (T4, T7), (T7, T2,) and (T2, T0) were nonsignificant to each other. However, all the treatments were significant over control.

\section{Average number of leaves per plant}

Perusal of data (Table 2 and Figure 2) revealed maximum average number of leaves/plant in Neem oil $+T$. viride treatment at 30, 60 and 90 days after sowing (68.25, 110.92 and 148.75 , respectively), followed by, Castor oil $+T$. viride treatment $(59.86,98.98$ and 142.66, respectively), Clove + T.viride treatment $(58.75,97.30$ and 139.11, respectively), Trichoderma viride treatment (58.16, 95.39 and 125.21, respectively), Neem oil treatment (55.62, 88.69 and 120.61, respectively), Clove oil treatment (54.32, 87.49 and 120.08, respectively), Castor oil treatment $(52.91, \quad 83.27$ and 118.77, respectively) and untreated check (47.36, 73.33 and 109.01, respectively). Among the treatments (T2, T7 and T3), (T5, T4,), (T4, T7), (T7, T2,) and (T2, T0) were nonsignificant to each other. However, all the treatments were significant over control.

\section{Average number of branches/plant}

Perusal of data (Table 3 and Figure 3) revealed maximum average number of branches/plant in Neem oil $+T$. viride treatment at 30, 60 and 90 days after sowing $(12.79,14.00$ and 14.71, respectively), followed by, Castor oil $+T$. viride treatment (12.53, 13.03 and 14.01, respectively), Clove + T.viride treatment (11.28, 12.16 and 13.31, respectively), Trichoderma viride treatment (11.25, 12.11 and 13.21, respectively), Neem oil treatment (10.91, 12.09 and 12.77, respectively), Clove oil treatment (10.14, 11.10 and 12.12, respectively), Castor oil treatment $(9.07,9.77$ and 10.38 , respectively) and untreated check (7.10, 8.08 and 8.61, respectively). Among the treatments (T2, T7 and T3), (T5, T4,), (T4, T7), (T7, T2,) and (T2, T0) were non-significant to each other. However, all the treatments were significant over control.

\section{First fruit picking}

Perusal of data (Table 4 and Figure 4) revealed maximum first fruit picking in Neem 
oil $+T$. viride treatment (56.08), followed by, Castor oil $+T$. viride treatment (59.56), Clove + T.viride treatment (61.29), Trichoderma viride treatment (63.08), Neem oil treatment (65.09), Clove oil treatment (66.29), Castor oil treatment (67.79) and untreated check (70.72). Among the treatments (T2, T7 and T3), (T5, T4,), (T4, T7), (T7, T2, ) and (T2, T0) were non-significant to each other. However, all the treatments were significant over control.

\section{Average number of fruits/plant}

Perusal of data (Table 4 and Figure 4) revealed maximum average number of fruits/plant in Neem oil $+T$. viride treatment (8.26), followed by, Castor oil $+T$. viride treatment (7.38), Clove + T.viride treatment (6.97), Trichoderma viride treatment (6.59), Neem oil treatment (6.51), Clove oil treatment (6.04), Castor oil treatment (5.64) and untreated check (5.51).

Among the treatments (T2, T7 and T3), (T5, T4,), (T4, T7), (T7, T2,) and (T2, T0) were non-significant to each other. However, all the treatments were significant over control.

\section{Average length of fruit}

Perusal of data (Table 4 and Figure 4) revealed maximum average length of fruits in Neem oil $+T$. viride treatment (18.41), followed by, Castor oil $+T$. viride treatment (16.38), Clove + T.viride treatment (15.35), Trichoderma viride treatment (14.21), Neem oil treatment (13.27), Clove oil treatment (12.54), Castor oil treatment (12.08) and untreated check (11.05). However, all the treatments were significant over control.

\section{Disease severity of leaf spot in bittergourd}

Perusal of data (Table 5 and Figure 5) revealed minimum disease severity in Neem oil $+T$. viride treatment at 30,60 and 90 days after sowing (7.07, 11.14 and 19.74, respectively), followed by, Castor oil $+T$. viride treatment $(8.84,15.45$ and 27.86, respectively), Clove + T.viride treatment (9.60, 16.57 and 29.47, respectively), Trichoderma viride treatment (12.08, 20.29 and 33.86, respectively), Neem oil treatment (14.78, 22.93 and 45.70, respectively), Clove oil treatment $(16.44,24.16$ and 45.99, respectively), Castor oil treatment (18.97, 24.96 and 47.40, respectively) and untreated check (29.05, 52.08 and 70.84, respectively).

Among the treatments (T2, T7 and T3), (T5, T4,), (T4, T7), (T7, T2,) and (T2, T0) were non-significant to each other. However, all the treatments were significant over control.

In the present study result experiment conducted the "Eco-friendly Management of Alternaria sp. causing Leaf spot of Bitter gourd (Momordica charantia. L)", under the appropriate fruiting carried out in rabi season 2019-2020 to asset the disease severity and growth parameters of crop under field condition.

The experiment was analyzed by using RBD (randomized block design) with three replication in a plot size $2 \times 2 \mathrm{~m}^{2}$, eight treatments neem oil $5 \%$, castor oil $5 \%$, clove oil 5\%, Trichoderma viride $5 \mathrm{gmlkg}$, Neem oil $2.5 \%+$ Trichoderma viride $2.5 \%$, castor oil $2.5 \%+T$.viride $2.5 \%$, clove oil $2.5 \%+$ Trichoderma viride $2.5 \%$ along with control. 
Table.1 Effect of treatments on plant height $(\mathrm{cm})$ of bitter gourd at 30, 60, and 90 DAS

\begin{tabular}{|c|c|c|c|c|}
\hline & Treatments & 30DAS & 60DAS & 90DAS \\
\hline $\mathbf{T}_{\mathbf{0}}$ & Control & 77.85 & 128.76 & 205.32 \\
\hline $\mathbf{T}_{\mathbf{1}}$ & Neemoil & 108.85 & 140.22 & 235.11 \\
\hline $\mathbf{T}_{\mathbf{2}}$ & Castoroil & 88.36 & 130.68 & 216.30 \\
\hline $\mathbf{T}_{\mathbf{3}}$ & Cloveoil & 93.97 & 135.15 & 220.09 \\
\hline $\mathbf{T}_{\mathbf{4}}$ & Trichodermaviride & 111.87 & 148.05 & 250.95 \\
\hline $\mathbf{T}_{\mathbf{5}}$ & Neem oil + T. viride & 121.29 & 168.11 & 280.64 \\
\hline $\mathbf{T}_{\mathbf{6}}$ & Castoroil+T.viride & 116.08 & 153.08 & 275.12 \\
\hline $\mathbf{T}_{\mathbf{7}}$ & Clove oil+T.viride & 112.88 & 150.21 & 260.60 \\
\hline & S.Ed( $\mathbf{(})$ & $\mathbf{0 . 6 0}$ & $\mathbf{0 . 5 9}$ & $\mathbf{0 . 4 2}$ \\
\hline & C.D.(0.05) & $\mathbf{1 . 3 0}$ & $\mathbf{1 . 2 9}$ & $\mathbf{0 . 9 2}$ \\
\hline
\end{tabular}

Table.2 Effect of treatments on average number of leaves of bitter gourd at 30, 60 and 90D AS

\begin{tabular}{|c|c|c|c|c|}
\hline \multicolumn{2}{|c|}{ Treatments } & 30DAS & 60DAS & 90DAS \\
\hline $\mathbf{T}_{\mathbf{0}}$ & Control & 47.36 & 73.33 & 109.01 \\
\hline $\mathbf{T}_{\mathbf{1}}$ & Neemoil & 55.62 & 88.69 & 120.61 \\
\hline $\mathbf{T}_{\mathbf{2}}$ & Castoroil & 52.91 & 83.27 & 118.77 \\
\hline $\mathbf{T}_{\mathbf{3}}$ & Cloveoil & 54.32 & 87.49 & 120.08 \\
\hline $\mathbf{T}_{\mathbf{4}}$ & Trichoderma viride & 58.16 & 95.39 & 125.21 \\
\hline $\mathbf{T}_{\mathbf{5}}$ & Neemoil+T.viride & 68.25 & 110.92 & 148.75 \\
\hline $\mathbf{T}_{\mathbf{6}}$ & Castoroil+T.viride & 59.86 & 98.98 & 142.66 \\
\hline $\mathbf{T}_{\mathbf{7}}$ & Cloveoil+T.viride & 58.75 & 97.30 & 139.11 \\
\hline & S.Ed( $\mathbf{(})$ & $\mathbf{0 . 9 0}$ & $\mathbf{0 . 6 6}$ & $\mathbf{0 . 5 8}$ \\
\hline & C.D.(0.05) & $\mathbf{1 . 9 5}$ & $\mathbf{1 . 4 3}$ & $\mathbf{1 . 2 5}$ \\
\hline
\end{tabular}

Table.3 Effect of treatments on average number of branches of bitter gourd at 30, 60and90 DAS

\begin{tabular}{|c|c|c|c|c|}
\hline & Treatments & 30DAS & 60DAS & 90DAS \\
\hline $\mathbf{T}_{\mathbf{0}}$ & Control & 7.10 & 8.08 & 8.61 \\
\hline $\mathbf{T}_{\mathbf{1}}$ & Neemoil & 10.91 & 12.09 & 12.77 \\
\hline $\mathbf{T}_{\mathbf{2}}$ & Castoroil & 9.07 & 9.77 & 10.38 \\
\hline $\mathbf{T}_{\mathbf{3}}$ & Cloveoil & 10.14 & 11.10 & 12.12 \\
\hline $\mathbf{T}_{\mathbf{4}}$ & Trichoderma viride & 11.25 & 12.11 & 13.21 \\
\hline $\mathbf{T}_{\mathbf{5}}$ & Neemoil+T.viride & 12.79 & 14.00 & 14.71 \\
\hline $\mathbf{T}_{\mathbf{6}}$ & Castoroil+T.viride & 12.53 & 13.03 & 14.01 \\
\hline $\mathbf{T}_{\mathbf{7}}$ & Cloveoil+T.viride & 11.28 & 12.16 & 13.31 \\
\hline & S.Ed( $\mathbf{n})$ & $\mathbf{0 . 5 1}$ & $\mathbf{0 . 3 6}$ & $\mathbf{0 . 2 8}$ \\
\hline & C.D.(0.05) & $\mathbf{1 . 1 0}$ & $\mathbf{0 . 7 8}$ & $\mathbf{0 . 6 1}$ \\
\hline
\end{tabular}


Table.4 Effect of treatments on first picking, average number of fruits/plant and average length of bitter gourd

\begin{tabular}{|c|c|c|c|c|}
\hline \multicolumn{2}{|c|}{ Treatments } & $\begin{array}{c}\text { First fruit } \\
\text { picking }\end{array}$ & $\begin{array}{c}\text { Average number } \\
\text { of fruits/plant }\end{array}$ & $\begin{array}{c}\text { Average } \\
\text { length of fruit }\end{array}$ \\
\hline T0 & Control & 70.72 & 5.51 & 11.05 \\
\hline T1 & Neemoil & 65.09 & 6.51 & 13.27 \\
\hline T2 & Castoroil & 67.79 & 5.64 & 12.08 \\
\hline T3 & Cloveoil & 66.29 & 6.04 & 12.54 \\
\hline T4 & Trichoderma viride & 63.08 & 6.59 & 14.21 \\
\hline T5 & Neemoil+T.viride & 56.08 & 8.26 & 18.41 \\
\hline T6 & Castoroil+T.viride & 59.56 & 7.38 & 16.38 \\
\hline T7 & Cloveoil+T.viride & 61.29 & 6.97 & 15.35 \\
\hline & C.D.(0.05) & $\mathbf{1 . 2 5}$ & $\mathbf{0 . 8 4}$ & $\mathbf{0 . 5 7}$ \\
\hline & S.Ed( $\mathbf{(})$ & $\mathbf{0 . 5 8}$ & $\mathbf{0 . 3 8}$ & $\mathbf{0 . 2 6}$ \\
\hline
\end{tabular}

Table.5 Effect of treatments on Disease severity of leaf spot ofbitter gourd at 30, 60 and 90 DAS

\begin{tabular}{|c|c|c|c|c|}
\hline & Treatments & 30DAS & 60DAS & 90DAS \\
\hline $\mathbf{T}_{\mathbf{0}}$ & Control & 29.05 & 52.08 & 70.84 \\
\hline $\mathbf{T}_{\mathbf{1}}$ & Neemoil & 14.78 & 22.93 & 45.70 \\
\hline $\mathbf{T}_{\mathbf{2}}$ & Castoroil & 18.97 & 24.96 & 47.40 \\
\hline $\mathbf{T}_{\mathbf{3}}$ & Cloveoil & 16.44 & 24.16 & 45.99 \\
\hline $\mathbf{T}_{\mathbf{4}}$ & Trichoderma viride & 12.08 & 20.29 & 33.86 \\
\hline $\mathbf{T}_{\mathbf{5}}$ & Neemoil+T.viride & 7.07 & 11.14 & 19.74 \\
\hline $\mathbf{T}_{\mathbf{6}}$ & Castoroil+T. viride & 8.84 & 15.45 & 27.86 \\
\hline $\mathbf{T}_{\mathbf{7}}$ & Cloveoil+T.viride & 9.60 & 16.57 & 29.47 \\
\hline & S.Ed( $\mathbf{n}$ & $\mathbf{0 . 4 3}$ & $\mathbf{0 . 5 6}$ & $\mathbf{0 . 6 0}$ \\
\hline & C.D.(0.05) & $\mathbf{0 . 9 3}$ & $\mathbf{1 . 2 2}$ & $\mathbf{1 . 3 0}$ \\
\hline
\end{tabular}

Fig.1 Microscopic view of Alternaria sp

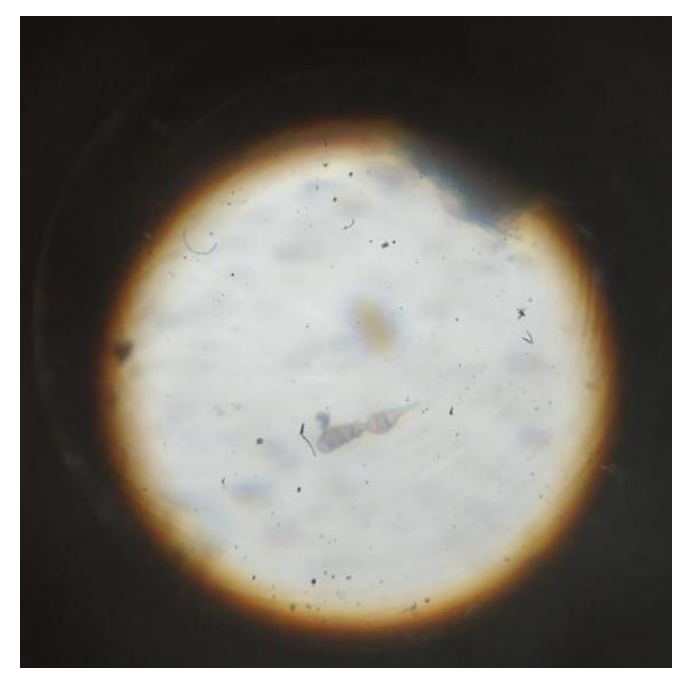


Fig.2 Infected leaf with Alternaria leaf spot

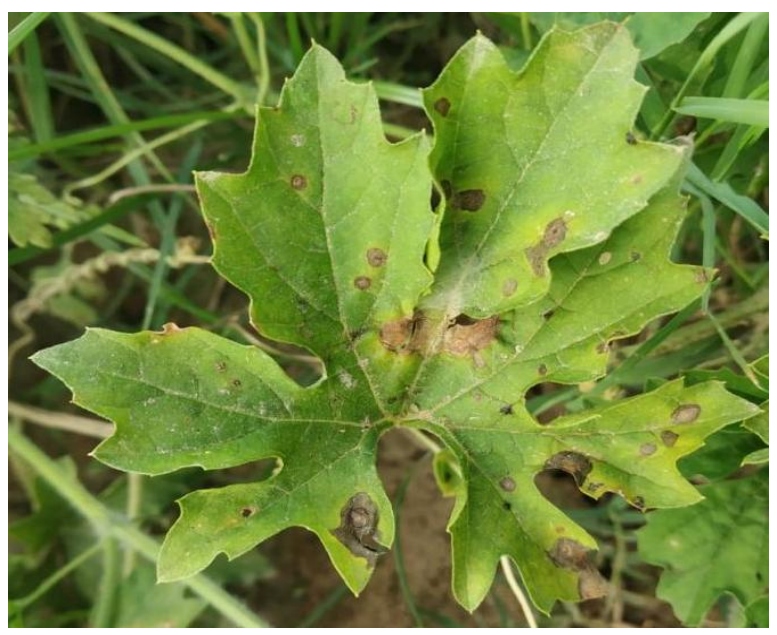

Fig.3 Effect of treatments on plant height $(\mathrm{cm})$ of bitter gourd at 30, 60 and 90 DAS

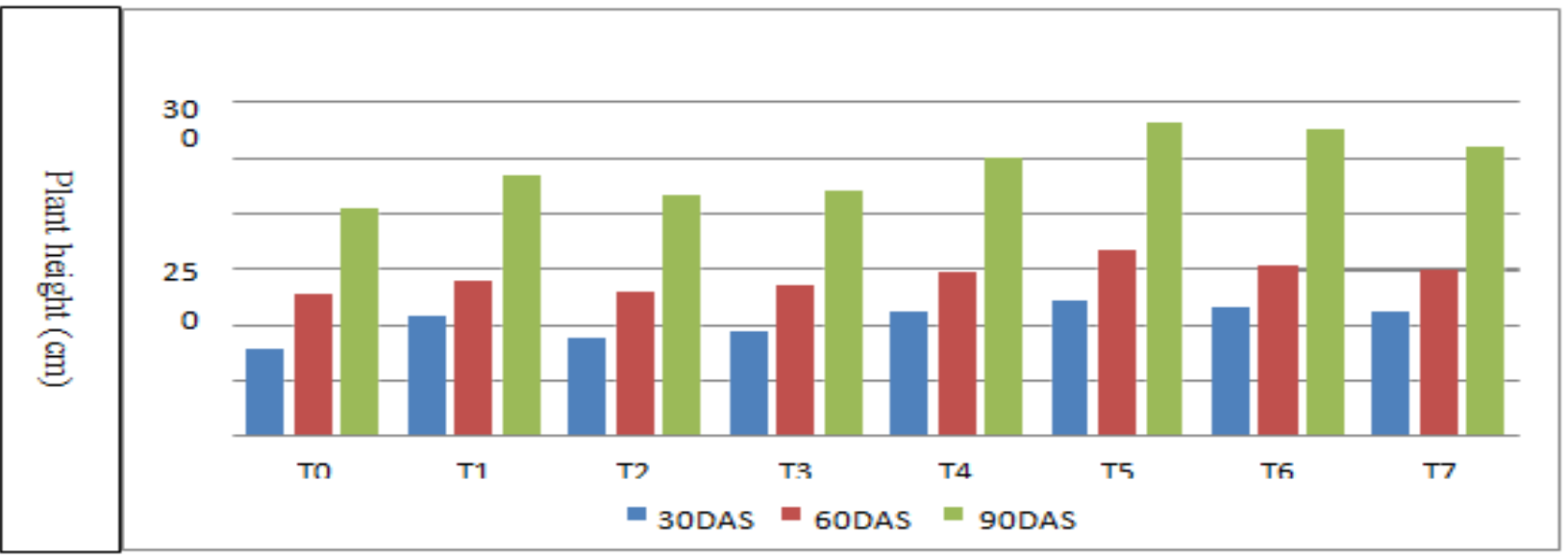

Fig.4 Effect of treatments on average number of leaves/plant of bitter gourd at 30, 60 and 90 DAS.

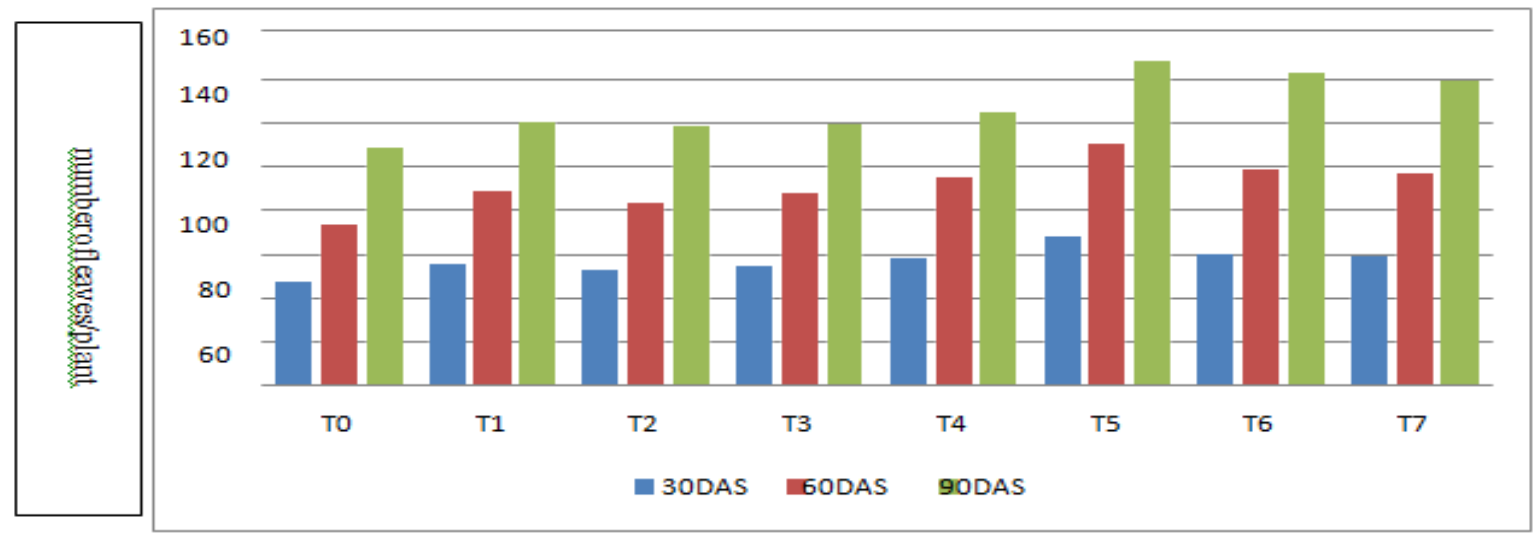


Fig.5 Effect of treatments on average number of branches of bitter gourd at 30, 60 and 90 DAS

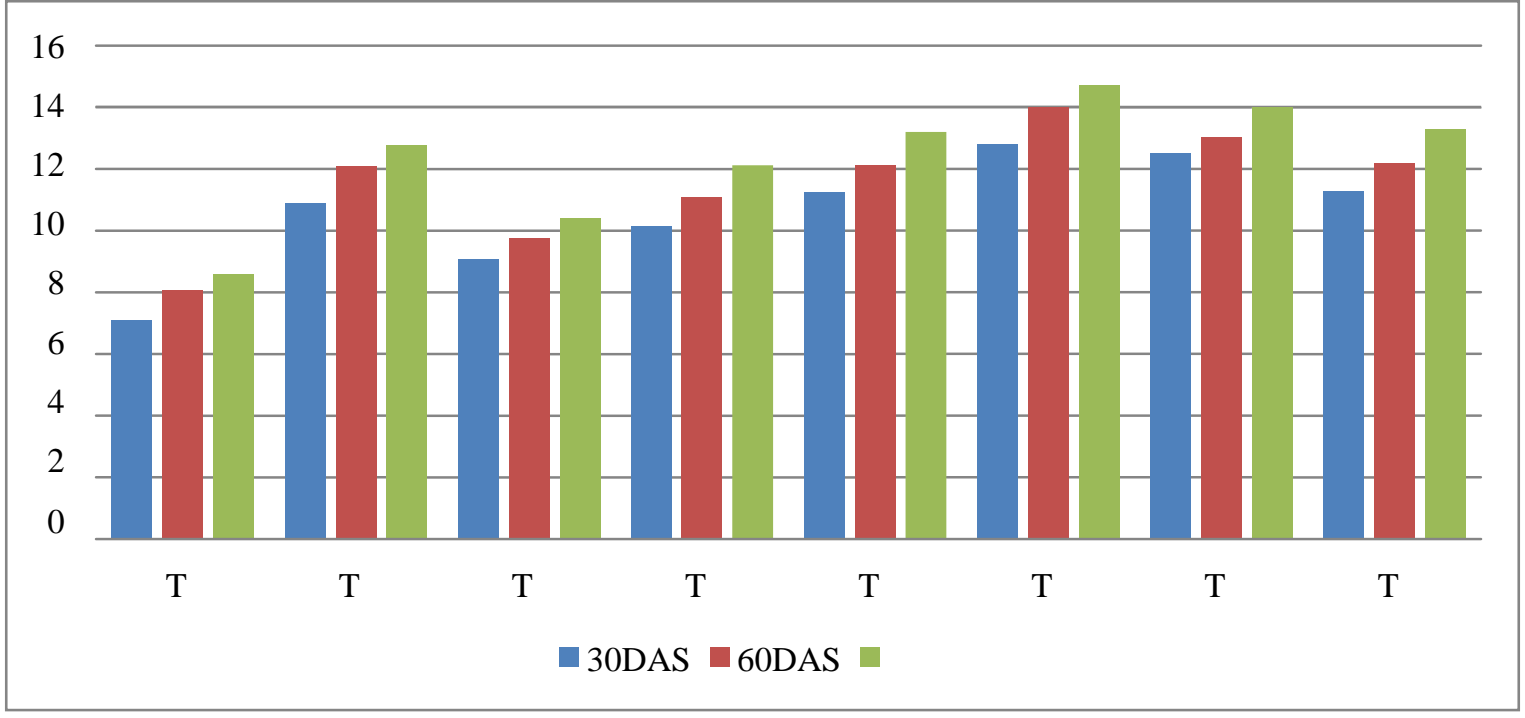

Fig.6 Effect of treatments of Bitter gourd first fruit picking

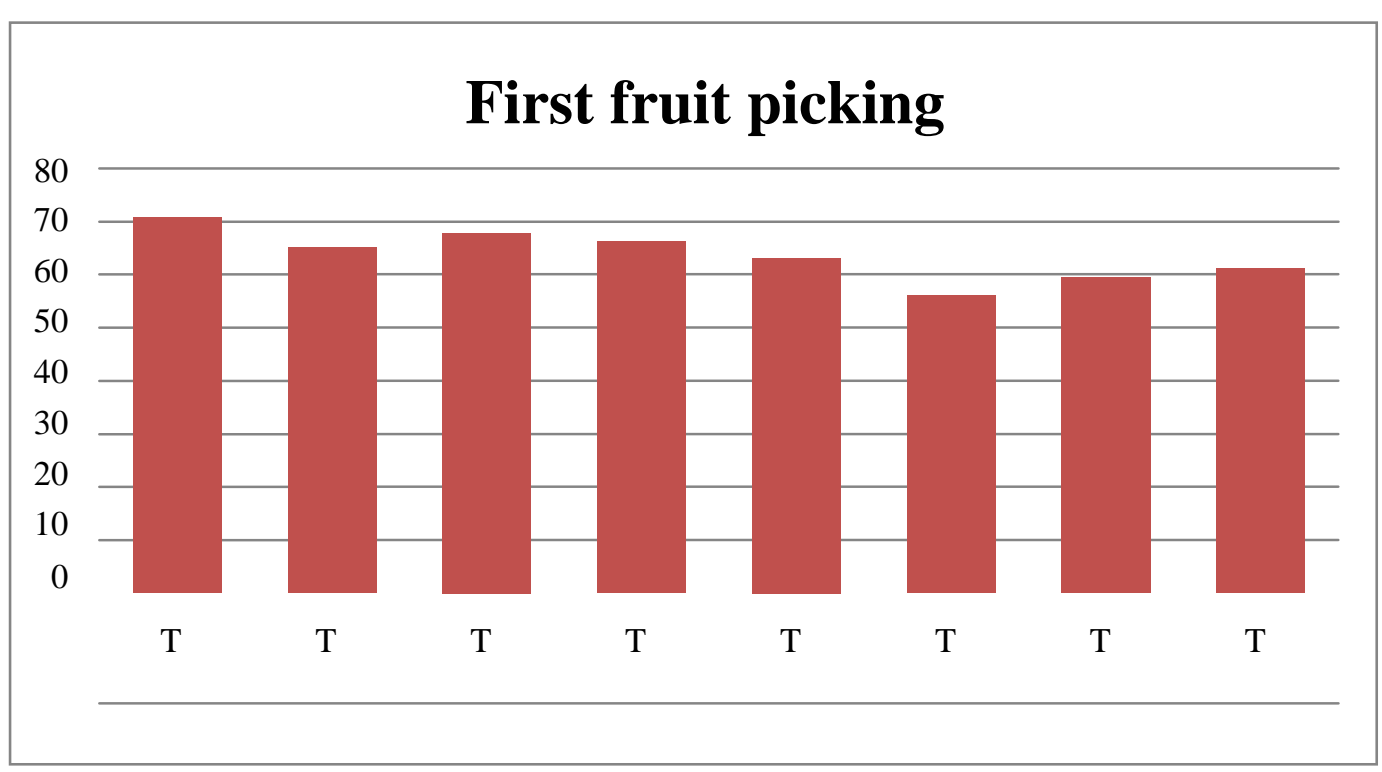


Fig.7 Effect of treatments on average number of fruits per plant of bitter gourd

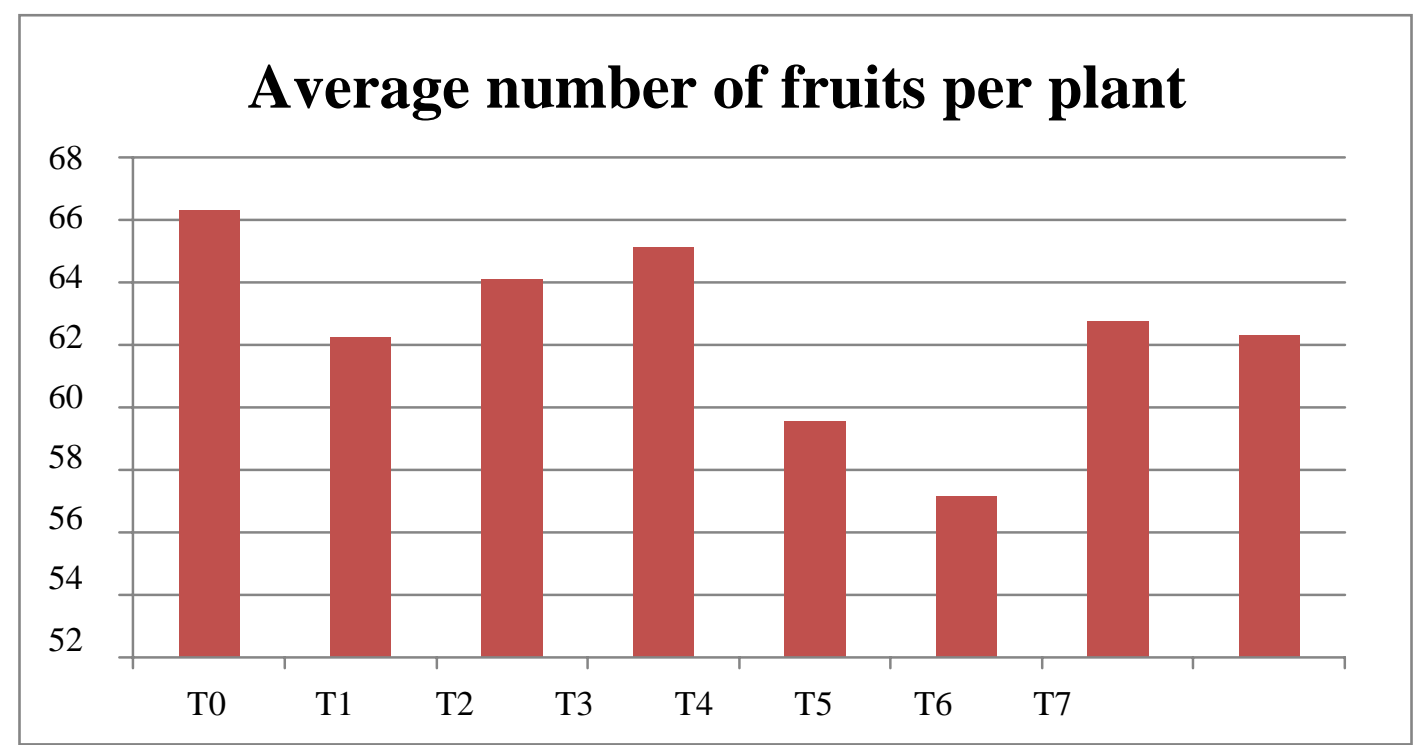

Fig.8 Effect of treatments on average length of fruit of bitter gourd

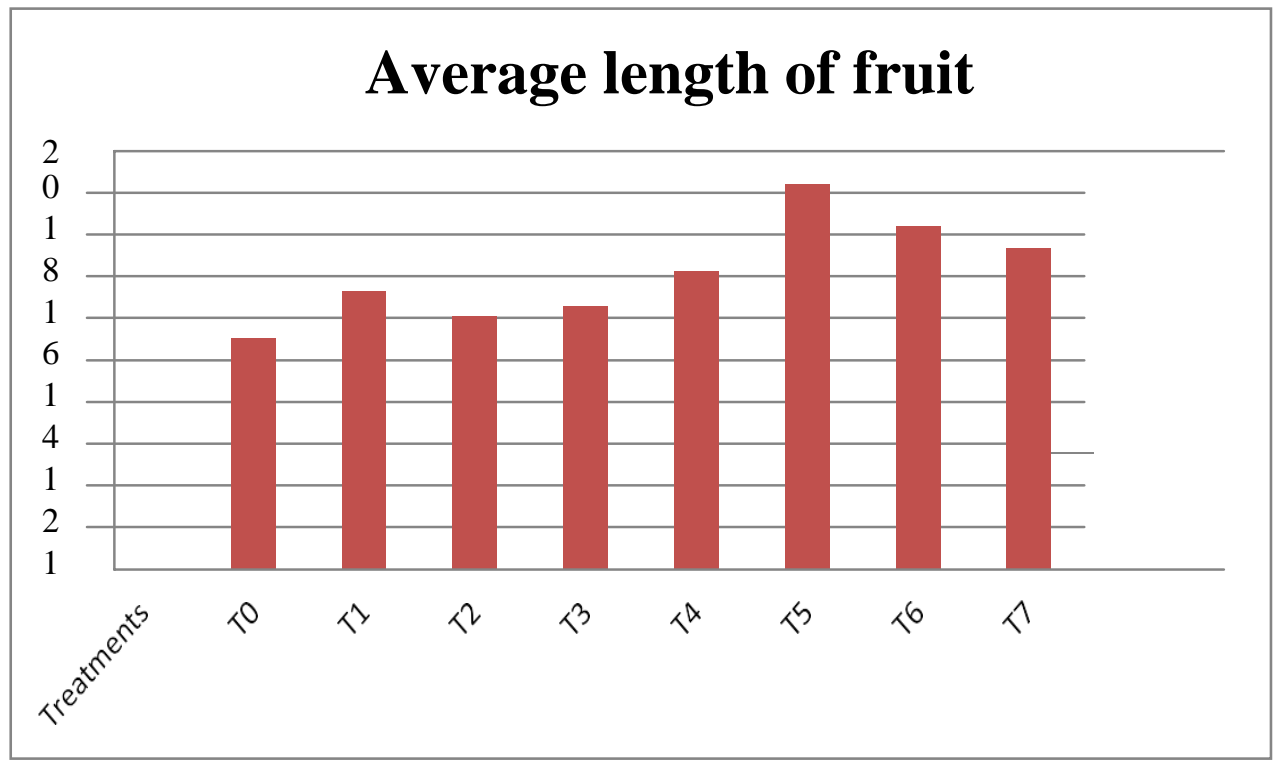


Fig.9 Effect of treatments on Disease severity of leaf spot ofbitter gourd at30, 60 and 90 DAS

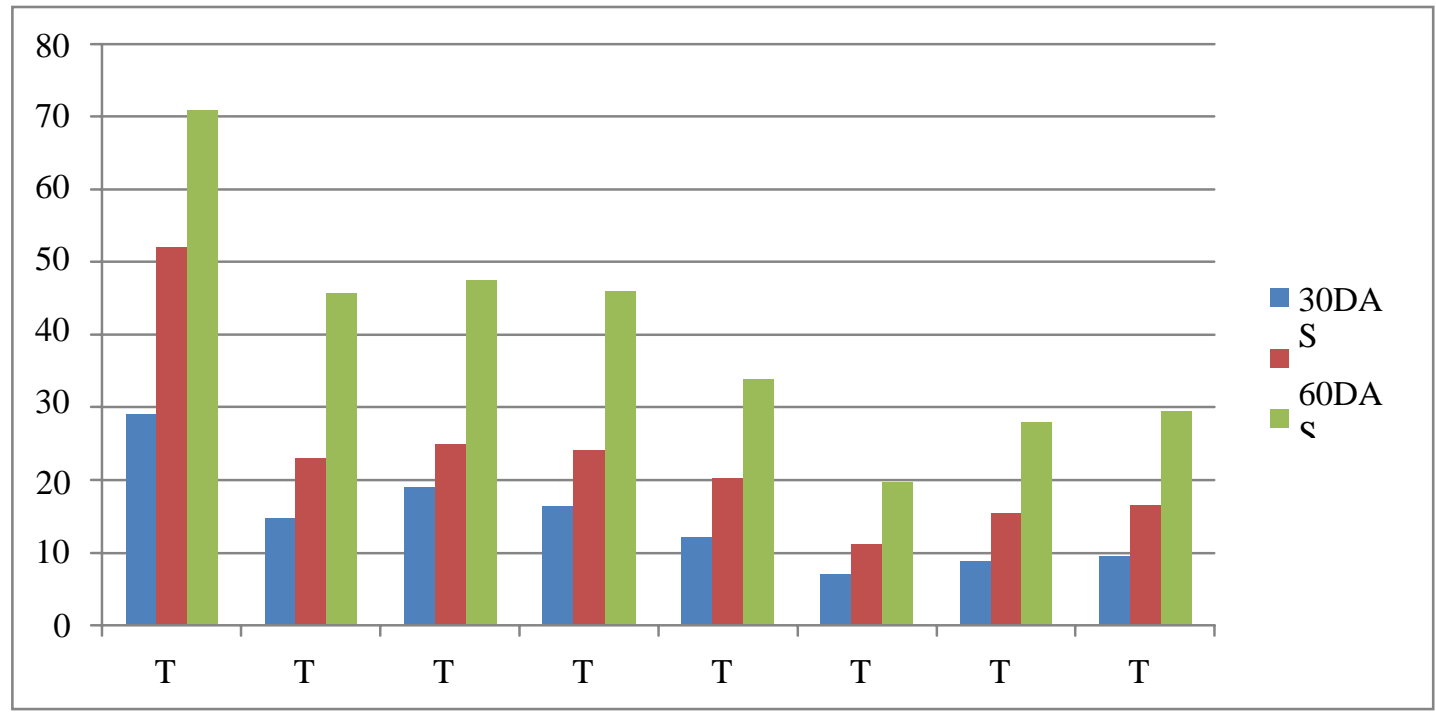

Observations were recorded disease severity at 30,60 and 90 DAS(days after sowing) and plant growth parameters such as plant height, number of leaves, number of branches, days to first fruit picking, average length of the fruits, fruits per plant. Experiment revealed that bioagents with combination of Trichoderma increased the growth parameters and it inhibits the disease severity\%. Thus, according to experimental findings and results discussed in earlier chapter, it was concluded that bioagents with combination Trichoderma reduced the Alternaria leaf spot of bitter gourd.

The concept of eco-friendly management have encouraged the plant protection specialist to go for use of bio-agents for the management of pests and diseases. Also this can avoid the pollution of air, water and soil.

The present study reveals that the bio-agent and neem oil as seed treatment is effectively working on Alternaria leaf spot disease management and has great impact on growth parameters. As the in-organic chemical use on crops is hazards to consumers and they leave the residues in soil which are harmful and loses the fertility of soil. Seed treatment with Neem oil @2.5\% + T. viride @2.5\% recorded minimum disease severity of Alternaria leaf spot and maximum plant growth parameters and yield. So it concluded that the Neem oil @ $2.5 \%+T$. viride @ 2.5\% is best bio resource for management of Alternaria leaf spot and has greater impact on growth parameters and yield. However, the present study was limited to one crop season under Prayagraj conditions, therefore to substantiate the present results more trials are needed for 2-3 seasons for further recommendation.

\section{References}

Abascal, K. and Yarnell, E. (2005).Alternative and Complementary Therapies. http://doi.org/10.1089/act.2005.11.179 $-184$.

Anonymous.(2018). Ministry of Agriculture, government of India. http:// agriculture gov.in/

Agoramoorthy. G., Venkatesalu. V, and M. J. Hsu. (2007). Antibacterial and antifungal activities of fatty acid methyl esters of the blind-your-eye mangrove from India. Brazilian Journal of Microbiology.38:739-742.

Amrutha Gayathri, D. and Krishna Rao, V. (2018).Evaluation of efficacy Neem 
oil, castor oil, carbendazim, Trichoderma harzianum, Trichoderma viride and Pseudomonas fluorescens against Alternaria carthami. International Journal of Plant Sciences.13(1) 90-92.

Barnett and Hunter (1998). Illustrated genera of imperfect fungi.4: 132.

Behera, T. K. D., Gaikwad, A, B., Swati Saxena., Bharadwaj, C. and Munshi, A. D. (2012). Morphological and molecular analyses define the genetic diversity of Asian bitter gourd (Momordica charantia L.) Australian Journal of Crop Sciences 6(2):261267.

Desai, U. T. And Musmade, A. M. (1998).Pumpkins, Squashes and Gourds. In: Handbook of vegetable science and bitter melons (Momordica charantia) and antioxidant activities of their extracts. Journal Food Science 70.

Divya, J., Yeshoda, R. H. and Rajashekar L. (2018). Bioefficacy of Essential oils and Plant oils for the management of Banana Anthracnose-A Major postharvest disease. International Journal of Current Microbiology and Applied Science. 7(4): 2319-7706.

Jakiemiu E. A., Scheer A. D., Oliveira J. S., Yamamoto C. I, and Deschamps C., (2010). Study of composition and yield of thymus vulgaris L. oil essential, Semina.,31(3):983- 688.

Kader, A. M. M., El-Mougy, N. S., Aly, M. D. E. and Embaby, E. I.(2012). Occurrence of Sclerotinia Foliage Blight Disease of Cucumber and Pepper Plants under Protected Cultivation System in Egypt II. BioControl Measures against Sclerotinia Spp. In-Vitro. Advances in Life Sciences. 2(4): 85-97.

Khan, F. M., Amin, M., Ullah, Z., Rehman, S., Amir, M, Ali, I. (2014). Distribution of
Alternaria Leaf spot of bitter gourd in district Peshawar and Nowashera, Khyber Pakhtunkhwa, Pakisthan Journal of Pharmacognosy And Phytochemistry, 2014;3(2): 211-215.

Kumar, S, K. V., Yogeswaran, P., Harani, A., Sudhakar, K., Sudha, P. and Banji, D. (20 10). A medicinal potency of Momordica charantia. International Journal of Pharmaceutical Sciences Review and Research,1(2):95.

Mathew, A V., and Alice, K. J., (2002). Transmission, host range and etiology of mosaic disease of bitter gourd. Indian Phytopath.55(2):219-220.

Nieman C. (1995). Influence of trace amounts of fatty acids on the growth of microorganisms. Bacteriol Reviews.18: 147-163.

Nadkarni, K. M., (1993). Indian Material Medica (1stEdn.) Popular Prakashan Pvt. Ltd., Bombay:805-806.

Palada, M. C. and Chang, L. C. (2003). Suggested cultural practices for bitter gourd. International Cooperators Guide, (3): 1-5.

Pratibha, S., Kadu, L. N. and Sain, S. K. (2005).Biological management of dieback and fruit rot of chilli caused by colletotrichum capsici(syd.) Butler and Bisby. Indian Journal Of Plant Protection, 33(2): 226-230.

Raj, S. K., Snehi, S. K., Khan, M. S., Tiwari, A. K. and Rao, G. P.(2010).First report of pepper leaf curl Bangladesh virus strain associated with bitter gourd (Momordica charantia L.) yellow mosaic disease in India. Australasian Plant Disease Notes, 5: 14-16.

Rai, N. and Yadav, D. S. (2005). Advances in Vegetable production. Research Publishing, New Delhi 2005, 325-337.

Rahmatzai, N., Zaitoun, A. A., Madkour, M. H., Ahmady, A., Hazim, Z., Magdi, A. A. M. (2017). In vitro and in vivo antifungal activity of botanical oils 
against Alternaria solani causing early blight of tomato. International Journal of Biosciences. 10(1), 91-99.

Ravishankar, L. V. and Shashi Tiwari.(2018). Biological management of Alternaria leaf blight in coriander (Coriandrum sativum).Journal of Pharmacognosy and Phytochemistry7(6): 1867-1869.

Skrivanova, E., Marounek, M., Dlouha, G., Kanka, J., (2005). Susceptibility of Clostridium perfringens to $\mathrm{C} 2-\mathrm{C} 18$ fatty acids. Letters in Applied Microbiology.41: 77-81.

Sprong, R. C., Hulstein, M. F. E., Van der Meer, R., (2001). Bactericidal activities of milk lipids. Antimicrob Agents Chemother.45: 1298-1301.

Warrier, P. K., Nambiar V. P. K. and Ramakutty, C. (1995). Indain Medicinal Plants: A Compendium of 500 Species. Orient Longman Pvt. Ltd., Hyderabad, India,. Journal of Pharmacy and Pharmacology.393394.

Win Nang, K, K., Kim Young-Hawan. and Jung Hee-Young.(2014).Bitter gourd little leaf disease associated to 'Candidatus Phytoplasmaasteris'. Tropical Plant Pathology, vol. 39(1):082-088, Brazilian Phytopathological Society.

\section{How to cite this article:}

Mounika Chavan, Shashi Tiwari, Mandala Mahesh and Katukamsairam. 2021. Eco Friendly Management of Alternaria sp. causing Leaf Spot of Bitter Gourd (Momordica charantia L.). Int.J.Curr.Microbiol.App.Sci. 10(06): 653-665. doi: https://doi.org/10.20546/ijcmas.2021.1006.072 